\title{
DISCUSIONES
}

\section{THE FORMALITIES OF EVIL AND A FINITE GOD}

MICHAEL MARTIN

Boston University

Some philosophers of religion have believed that given the assumption of a finite God, the problem of evil disappears. ${ }^{2}$ In particular they have not supposed that a contradiction can be deduced from assumptions usually associated with belief in a finite God. In a recent article, ${ }^{2}$ Douglas. Walton has shown how a contradiction can be deduced from alleged necessary truths and theistic assumptions about a God that is all good and all powerful. I will present here a formulation of an argument from evil similar to Walton's, using instead of the assumption that God is all powerful simply the assumption that God is more powerful than man. In short, I will show that if Walton's formalization of the argument from evil is sound, an argument from evil based on a finite God is sound as well. I will argue, however, that one of the alleged necessary truths used by Walton and an analogous alleged necessary truth I use are incorrect; they are not only not necessary, they are not even true. Consequently, the argument I initially present must be revised. One of the premises in the revised argument cannot be established conclusively, but it can be confirmed by an inductive argument.

\section{I}

Walton states informally some of the premises used to gen. erate the problem of evil:

1 See, for example, Terence Penelhum, Religion and Rationality (New York: Random House, 1971), p. 226.

2 Douglas Walton, "The Formalities of Evil," Critica, VII, 22, abril 1976, pp. 3-6. 
(1) A good being always prevents evil if he can.

(2) An omnipotent being can prevent anything.

(3) A good, omnipotent being prevents all evil.

(1) and (2) are alleged to be necessary truths and (3) follows from (1) and (2).

In my argument $(1),(2)$ and (3) are replaced by:

( $\left.1^{\prime}\right)$ A good being that is more powerful than man prevents any evil if the evil can be prevented by man.

$\left(2^{\prime}\right)$ A being more powerful than man can prevent anything man can.

$\left(3^{\prime}\right)$ A good being that is more powerful than man prevents all evil that man can prevent.

$\left(1^{\prime}\right)$ is a necessary truth if $(1)$ is. $\left(2^{\prime}\right)$ is a necessary truth. $\left(3^{\prime}\right)$ follows fron $\left(1^{\prime}\right)$ and $\left(2^{\prime}\right)$.

Now undefined predicate expressions are introduced:
G (1) : (1) is good
P (1) (2): (1) prevents (2)
$M$ (1) : (1) is more power. ful than any
C (1) (2): (1) can prevent (2) man if any man can prevent (2)

B (1) : (1) is bad

The first-order predicate structure of $\left(1^{\prime}\right),\left(2^{\prime}\right)$ and $\left(3^{\prime}\right)$ becomes:

(4) (x) $(G x \cdot M x \supset(y)(B y \supset(C x y \supset$ Pxy $)))$

(5) (x) (Mx $\supset(\mathrm{y})(\mathrm{Cxy}))$

(6) (x) (Gx $\supset(M x \supset(y)(B y \cdot C x y \supset P x y)))$

Next it is assumed that a finite God exists:

(7) $(\exists x)(G x \cdot M x)$

and that evil exists that can be prevented if any man can prevent it. 


$$
(\exists x)(\exists y)(B x \cdot C y x)
$$

Given a premise assumed by Walton that appears to be a necessary truth"

$$
(\exists \mathrm{x})(\mathrm{y})(\mathrm{By} \text { Pxy) } \supset \sim(\exists \mathrm{z})(\mathrm{Bz})
$$

we can deduce

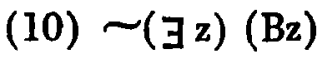

which conflicts with (8).

One may classify the premises of the argurirent as follows. (7) and (8) are assumptions essential to the finite God position. (4), (5) and (9) are allegedly necessary truths $((9)$ is also assumed by Walton).

\section{II}

However, a premise in Walton's formulation is false and a premise on my formulation of the argument from evil is also false. In Walton's formulation, (1) is false. A good being will not necessarily prevent any had thing if he can since he might have a sufficient reason for allowing the bad, thing to exist. ${ }^{*}$ My premise $\left(1^{\prime}\right)$ and consequently (4), the formal version of $\left(1^{\prime}\right)$, is false. A good being that is more powerful than man will not necessarily prevent evil if the evil can be prevented by man for he may have a sufficient reason for allowing it. One sufficient reason might be that preventing an evil might bring about more evil than not preventing it. (4) therefore needs to be reformulated.

Let us introduce the following predicate expressions:

$B^{\prime}$ (1) : (1) is inexplicably bad.

S (1) (2): (1) is a sufficient reason for allowing (2),

\$ I am ignoring here the technical logical problems Walton raises about this premise.

\& See, for example, N. Pike, "Hume on Evil," in God and Evil, N. Pike (ed.) (N. J.: Prentice-Hall, 1964) for this part. 
Then the notion of inexplicable evil can be defined as follows:

(11) $(\mathrm{x})(\mathrm{y})\left(\mathrm{B}^{\prime} \mathrm{x} \equiv \mathrm{Bx} \cdot \sim \mathrm{Syx}\right)$

Then (4) becomes $\left(4^{\prime}\right)$ which does seem to be a necessary truth:

$\left(4^{\prime}\right) \quad(\mathrm{x})\left(\mathrm{Gx} \cdot \mathrm{Mx} \supset(\mathrm{y})\left(\mathrm{B}^{\prime} \mathrm{y} \supset(\mathrm{Cxy} \supset \mathrm{Pxy})\right)\right)$.

(6), (8), and (9) become:

$\left(6^{\prime}\right)(\mathrm{x})\left(\mathrm{Gx} \supset\left(\mathrm{Mx} \supset(\mathrm{y})\left(\mathrm{B}^{\prime} \mathrm{y} \cdot \mathrm{Cxy} \supset \mathrm{Pxy}\right)\right)\right)$

(8') ( $(\exists x)(\exists y)\left(B^{\prime} y \cdot C y x\right)$

(9') ( $3 x)(y)\left(B^{\prime} y\right.$ Pxy) $\supset \sim(\exists z) B^{\prime} z$.

Now $\left(4^{\prime}\right),\left(5^{\prime}\right),\left(6^{\prime}\right),\left(8^{\prime}\right),\left(9^{\prime}\right)$ lead to a contradiction. However, $\left(8^{\prime}\right)$ is not something that is accepted by most theorists of the traditional or finite God variety. Furthermore, there seems to be no inclusive way of establishing $\left(8^{\prime}\right)$. This becomes clear when we look at (11). For no matter how many proffered sufficient reasons are examined and rejected $\left(8^{\prime}\right)$ is not conclusively established.

Nevertheless, it does seem possible to confirm $\left(8^{\prime}\right)$. Suppose that all proffered sufficient reasons given by theists and finite God apologists until now have been examined and found wanting. This would give us good reason (but not a conclusive reason) to suppose that $\left(8^{\prime}\right)$ is true. Consequently, it should give us good reason to accept $\left(8^{\prime}\right)$ and reject (7) given that the other premises of the argument are true. This inductive type of reasoning is used in other areas of inquiry and there seems to be no good reason not to use it here.

I conclude then that an argument from evil can be formulated that leads to a contradiction and that it is based on the assumption of a finite God. This argument does not contain any obviously false premise but one crucial premise of the argument is not accepted be believers in a finite God. This premise can be supported by an inductive type argument. Whether this premise is so supported is another question. ${ }^{5}$

- However, it has been argued elsewhere, see Edward H. Madden and Peter H. Hare, Evil and the Concept of God (Springfield: Charles E. Thomas), 1968. 